\title{
Effects and Risks of Mergers and Acquisitions on Entrepreneurship in Banking and Finance: Empirical Study from Slovakia
}

\author{
Dana Kiselakova $^{1} \&$ Beata Sofrankova ${ }^{1}$ \\ ${ }^{1}$ Department of Finance, Faculty of Management, University of Presov, Presov, Slovak Republic \\ Correspondence: Dana Kiselakova, Department of Finance, Faculty of Management, University of Presov, \\ Presov, Slovak Republic. Tel: 421-51-7715-699. E-mail: dana.kiselakova@unipo.sk
}

\author{
Received: October 30, 2014 Accepted: February 3, 2015 Online Published: May 14, 2015 \\ doi:10.5539/res.v7n7p23 URL: http://dx.doi.org/10.5539/res.v7n7p23
}

\begin{abstract}
This study examines effects of mergers and acquisitions on entrepreneurship in the banking industry and identifies substantial factors of changing in its financial performance and risks from aspect of bank profitability in the economy of Slovakia, using regression modelling. The relationships between the dependence of the profitability of banking sector and selected financial indicators from aspect of its performance have been surveyed spanning a period of nine years (2004-2012). The research problem is as following: Do mergers and acquisitions create a value added and are desirable or more risky from financial aspect in the market economy. The task of this study is to use the financial analysis and project a multiple regression model (using data 1997-2011) to determine the success level of bank merger/acquisition between CSOB Bank and ISTROBANK in 2009, operating on the Slovak banking market. In the research hypotheses we investigate if the real profit development strengthened due to the impact of the bank merger/acquisition and impact of risks due to the global crisis on the financial performance. The novel designed linear regression model with seven independent variables, based on the methodology of empirical studies, compares the estimated and real profit development before and after bank merger/acquisition (2009-2011) as well. Our findings indicate that comparable models based on the existence of common relationships and dependences can be applied in other countries of the EU and present implications for decisions-making in the field of the increase global financial performance, trends and growth strategies of commercial banks.
\end{abstract}

Keywords: banking industry, effects, financial performance, mergers and acquisitions, profit development, the novel regression model

\section{Introduction}

There is a growing importance of mergers and acquisitions in financial services sector as a result of increasing globalisation and integration on global financial markets in the global economy. Nowadays, the research question arises how significant, profitable or risky these ways of gaining and investing capital are, therefore, ways are being determined to quantify the significant indicators, which most of all influence the success rate of mergers and acquisitions in the banking industry. Authors from the European Central Bank, in their empirical study of 2004, examined the impacts of EU bank's strategic similarities on post-merger performance with a use of the regression analysis. Several financial indicators were involved in the analysis with the aim to define strategic features of banks involvement in domestic and cross-country mergers in the EU in relation to their performance. These indicators included a measuring of financial performance, structure of assets and liabilities, capital structure, liquidity, risks, profitability, financial innovation and efficiency. Authors have found, on average that bank mergers have resulted in improved performance of banks.

The main task of this study is to determine the success level of the bank merger/acquisition between two commercial banks, operating on Slovak banking market, CSOB Bank and ISTROBANK using the financial analysis and create a novel regression model. In its analytical part, the study draws on other important empirical studies, too, most such as those by Cornett and Tehranian (1992) or Punt and van Rooij (1999), and Altunbas and Marques (2008). Identified factors of performance and risks show common features for the banking sectors in other countries of the EU in context of global crisis and proceeding impacts of global crisis based on existence of common relationships and dependences. These facts and effects of mergers and acquisitions present implications for decisions-making in the field of the stability of financial performance of commercial banks and resistance against global risks. 
The objective and main task of this study is to use the financial analysis and project a regression model (using annual data 1997-2011) to find out the success level of bank merger/acquisition between CSOB Bank and ISTROBANK in 2009, operating on the Slovak banking market within the EU. The novel model, based on the methodology of the empirical European studies, compares the estimated and real profit development after the bank merger/acquisition, accurately reflects the real bank development and can predict next development and trends in the area of the financial stability and performance of mergered CSOB Bank Slovakia with the real experience for the banking industry.

The research questions in this study to scientific and economic discussion are as follows: Do mergers and acquisitions create a value added and are desirable or more risky from financial aspect in the market economy? Based on mergers and acquisitions with focus on bank mergers and acquisitions is possible predict development trends in the area of financial performance of banking industry in the global economy?

The next section describes the theoretical basis and draws on experience on other empirical studies important for the European banking sector. Further section presents the methodology and methods used in this research and specify the regression model. Follow-up sections describe a brief empirical analysis of banking sector in Slovakia, presents the empirical financial and regression analysis for bank merger/acquisition and creating a novel regression model. Finally, last section summarises the main findings and empirical results as well as the implications for economic decisions - making in the field of the increase financial performance of commercial banks and the prevention towards risks.

\section{Literature Review}

The issue of mergers and acquisitions (M\&A) in terms of individual and corporate motives and strategies is a substantial part of the economic and management theory (Heckova et al., 2012). Banking literature has been intensely devoted to the issue of mergers and acquisitions in recent decades, the advantages, disadvantages, procedures of the realization processes of mergers and acquisitions are being explored, and in particular, considerable attention is paid to the issue of calculating the actual market value of the acquired entity (a bank), which has the predominant influence when determining an acquiring value (Sobek, 2000). One of the most important reasons for M\&A is undoubtedly the process of globalization, which forced the banking sector to increase long-term efficiency while creating a wide space for global M\&A, the volume of which increased at the end of the last century and peaked in 2000, what was observed by Heckova and Chapcakova (2009). Next activities in M\&A in banking industry continue worldwide (PWC, 2013; Sofrankova, 2013).

Following can be considered the basic objectives of M\&A in this period: achieve the scale for global business, strengthening of the main entrepreneurships' activities, achieve product and territorial diversification and new long-term investments, what is stated by Poloucek et al. (2006, pp. 476-477). Activities in the field of M\&A are based on the individual strategies of companies, mainly influenced by changes in the global economic environment, as well as by significant technological innovations. Individual waves of M\&A took place mostly during the growth of the world economy and concluded as a result of various crises or cooling of the world economy. Since the strategic goals and objectives are reasons for companies' equity or stock acquisitions, it is necessary to summarize the substantial arguments that play an important role in framing options for mergers and that should be declared to the management of each company, so they even consider the merger as one of the acceptable options (Walter, 2004; Smolkova, 2009, pp. 145-146):

1) Compatibility of strategic objectives, the possibility of designing the strategy for the newly established company

2) Potential for the future firm's growth — growth strategy and the increase of the market share

3) Potential for competitive advantages and their use on global market and global performance

4) Potential for synergic effects - which should occur during and after the merger

5) Economies of scale

In advanced research, this study also relies on other important studies such as studies by Cornett and Tehranian or Punt and van Rooij. Cornett and Tehranian (1992) in their publication Productivity Effects of Bank Mergers followed the performance of 30 large US banks in the post-merger period from 1982 to 1987. Overall, they found, banks that had implemented merger achieved better performance than other banks. Higher performance is under the study caused probably by increased attractiveness of credit and deposit products, employee performance and profitable asset growth. To analyse the sources of the increase in cash flow, indicators such as the share of income and expenses, the share of capital and assets, the share of loans and assets, the share of deposits and assets, liquidity, etc. were selected (Cornett \& Tehranian, 1992). Houston and Ryngaert (1994) 
demonstrated that the overall gains from a recent sample of bank mergers were slightly positive but statistically indistinguishable from zero and the methods of financing and the market perceives as most valuable.

Punt and van Rooij in their study The Profit-Structure Relationship and Mergers in the European Banking Industry: An Empirical Assessment confirmed that the current international mergers produce positive effects in relation to the efficiency and profitability of banks. The authors used data running from 1992 to 1997 and investigated variables between market structure variables and profitability variables, such as net interest on provided loans, net income from securities trading, net income from clients' deposits, the share of loans and assets and others (Punt \& van Rooij, 1999, pp. 13-14).

An important presumption for the financial performance, stability, rate of return and competitiveness of European commercial banks is the efficient management of their assets-and-liabilities structure, what is mentioned by Bobakova (2003, p. 27) and especially the management of credit transactions within the risk management framework. One of the main risks that affect the financial stability of the commercial banks in connection with business activities is credit risk associated with movements on credit markets. Empirical studies (Stavarek \& Sulganova, 2009; Lepetit et al., 2008) dealt with the analysis and investigation of the relationship between selected macroeconomic and sectoral indicators, considering the financial stability of economies, competitiveness, efficiency and profitability of commercial banks. Commercial banks aim to achieve the requested long-term profitability, shareholder economic value and profitability of the credit portfolio on a consistent and long-term basis, in accordance with the bank's adopted objectives and strategies, through credit risk management, accented Dietrich and Wanzenried (2011) and Cipollini and Fiordelisi (2012).

Financial institutions are developing newer and more progressive procedures and creating effective positions (risk managers) to increase the financial performance and efficiency of banking risk management (Poloucek et al., 2006; Aebi et al., 2012). Simultaneously, they seek newer approaches (advanced approaches), new financial instruments and models for the transfer of financial risks, what is emphasized by Sivak, Gertler, and Kovac (2009) and Horvathova and Mokrisova (2013). Central regulators make an effort to identify the substantial global factors with an impact on a bank distress and predicting distress in European banks, using many sophisticated methodologies and macroeconomic models.

\section{Methodology and Data}

\subsection{Financial Analysis and a Regression Model Applied in the Bank Merger/Acquisition CSOB Bank of} ISTROBANK in Slovakia

The objective of this study is to use the financial analysis and project a regression model (using annual data 1997-2011) to determine the success level of bank merger/acquisition between CSOB Bank and ISTROBANK in 2009, operating on the Slovak banking market within the EU, compare the estimated and real profit development after bank merger and summarise substantial factors, risks and effects of merger/acquisition for economic decisions-making in the field of the increase financial performance, market share and entrepreneurship of commercial banks.

The financial analysis in general means to calculate financial ratios for the business entity; in this case the data are from CSOB Bank and ISTROBANK, which are mainly based on the annual reports for the reporting period from 1997 to 2008. Thus calculated parameters are compared with the average indicators for the relevant branch of activity. Also the development of business characteristics at the time is being examined and consequently relations between evaluative financial indicators are analysed, for the period 2009-2011.

Based on the available data from CSOB Bank and ISTROBANK analysis using ratios was performed, but it was necessary to modify some of the characteristics from proportional to differential, since preliminary analysis reached values that were insignificant in terms of the research. Because of the influence of this factor, at first the financial analysis on the basis of differential and proportional ratios was performed, and then the regression analysis. The regression analysis is among the most important econometric tools and is used for quantitative description of the relationship between economic and financial variables. Its task is to explain the changes in value of one variable caused by changes in other variables. Altunbas and Marques (2004, pp. 14-15) in their study from 2004 examined the impact of the merger on the performance of banks using the regression analysis. They incorporated several financial indicators into the analysis in order to define the strategic features of the banks involved in domestic and cross-border mergers in the EU in relation to their performance.

The financial indicators for Slovak bank were selected on the basis of the European study from 2004, further empirical studies and available statistical data. These indicators are explanatory, independent variables, which are generally referred to as $x_{1 t}, x_{2 t}, \ldots, x_{7 t}$ and are used to build the general regression model. 
In this study, the following indicators were analysed and compared (the structure of key variables according to the methodology of the National Bank of Slovakia):

1) Difference between the amount of customer deposits received from clients and loans ( $\left.v k u k, \mathrm{x}_{1}\right)$

2) Difference between interest income and expenses (uvun, $x_{2}$ )

3) Difference between other operating income and operating expenses (opvpn, $x_{6}$ )

4) Difference between total capital and liabilities $\left(s k c k, x_{3}\right)$

5) Difference between receivables (the amount of loans provided to clients) and value adjustments and reserves to cover credit risk, valuation allowances ( $p r o p, x_{4}$ )

6) Liquidity ratio (quick ratio) of current assets and current liabilities (liq, $\left.x_{5}\right)$ to assess liquidity risk

7) Share of net operating income and total assets $\left(c p p \_a, x_{7}\right)$.

The regression model was constructed on the basis of selected indicators; the explained, the dependent variable was the net operating profit, $y_{t}$.

Then the linear regression model has the following form (Cipra, 2008):

$$
y_{t}=\beta_{0}+\sum_{t=1}^{N} \sum_{i=1}^{7} \beta_{i t} x_{i t}+\varepsilon_{i t}
$$

In this study, the influence of seven independent variables on one dependent, response variable has been investigated and to do so multiple linear regression model was used. Generally, the regression model has the following shape:

$$
y_{t}=\beta_{0}+\sum_{t=1}^{N} \beta_{1} x_{1 t}+\beta_{2} x_{2 t}-\beta_{3} x_{3 t}+\beta_{4} x_{4 t}-\beta_{5} x_{5 t}-\beta_{6} x_{6 t}+\beta_{7} x_{7 t}
$$

In this study, the specific variables are in the following format (3):

$$
\text { profit }_{t}=\beta_{0}+\sum_{t}^{2008} \sum_{1} \beta_{1} v k u k_{t}+\beta_{2} u v u n_{t}-\beta_{3} s k c k_{t}+\beta_{4} \text { prop }_{t}-\beta_{5} l i q_{t}-\beta_{6} o p v p n_{t}+\beta_{7} c p p \_a_{t}
$$

When analysing time series, it is necessary to determine their (non)stationarity. The stationarity of time series means that the behaviour of these series is in some sense stochastically settled. Scattering of stationary time series is constant and also covariance structure of the series does not change with time (correlation between first and second year of the stationary series remains in all subsequent years equal, by Cipra, 2008). If data are not stationary (which is a common phenomenon in economic parameters) is necessary to adjust the data. For this adjustment is usually used differential or data logarithm. The regression analysis requires a determination of the appropriate type model and then calculations of the best estimate of its parameters. For this purpose, several methods are used. Of these, the method of least squares is considered the most universal and allows determining the best estimate of the vectors of parameter $\beta$. It also provides estimates of the optimal properties for small samples and observation, as it is the case here, since the available period is relatively short.

The total $F$-test of the research hypothesis or the significance of $\mathrm{F}$ expresses the significance or reliability of the model as a whole. P-value, $P$-test expresses a probability of the significance of each parameter. The level of significance $\alpha$ is $5 \%$, i.e. 0.05 . The disadvantage of the method of the linear regression is a disability to catch the nonlinear dependence between variables and other external influences.

The research objective is to project a multiple regression model based on the available historical CSOB Bank data prior to the merger/acquisition, using the statistical software STATA. Using this model, the attention is focused on the estimation of net operating income in subsequent periods, i.e. after the merger. For this analysis data for the period 1997-2008 are used. These estimated values are compared to the real data about net operating profit of CSOB Bank for the same period after the merger/acquisition (2009-2011) and effects of the merger on the change in dynamics of CSOB Bank Slovakia profit development before and after the merger/acquisition are examined. 
The research hypotheses, tested in this study, are as follows:

$H_{l}$ : We assume that the bank merger/acquisition has direct positive effect on the dynamics of CSOB Slovakia profit development. We assume that the profit development strengthened due to the impact of the bank merger/acquisition in national economy.

$\mathrm{H}_{2}$ : We assume that the development of financial risks over time will increase, will have a negative impact on the financial performance of CSOB Bank Slovakia.

We examine whether the merger/acquisition influenced negatively or positively the development of CSOB Slovakia profit and impact of financial risks (bank liquidity risk, credit risk) on financial performance. The comparison with the actual data will verified whether the projected regression model of profit development. The regression model can be an appropriate and credible instrument for predicting trends and future earnings of CSOB Slovakia and will affect the financial performance, market share and financial stability on the banking market.

\section{Results and Discussion}

\subsection{Banking Sector in the Slovak Republic-A Brief Empirical Analysis}

Banking sector in Slovakia can be categorized as an economy branch that has undergone the significant quality, quantity - and dynamic changes and complicated processes during its development. The processes of restructuralization, recapitalization and privatization, financial consolidation, international integration, mergers, acquisitions and entering of foreign capital after 2000 considerably contributed to the formation of a modern banking sector and to the increase of international competitive environment (Kiselakova et al., 2011). On the other hand, the efficient regulation of banking sector within the international scope appears to be necessary in connection with the maintenance of its financial stability and liquidity, performance and competitiveness in the euro area and global macroeconomic environment.

Within the framework of the methodology the main problematic fields, which create the platform for scientific and economic discussion are analysed:

- The analysis of current status of financial performance of banking sector in Slovakia (29 commercial banks, incl. branches of foreign banks) in relation to selected indicators of banking rate of return, balance structure and indicators of the growth of economy in Slovakia within the EU, the analysis of financial performance of banking sector of Slovakia from the aspect of profitability - the empirical sectoral analysis (Kiselakova, 2010, p. 10).

Table 1, the trend analysis shows the dynamics of the development of profitability indicators, balance sheet structure and net interest income of the banking sector, from the aspect of performance and stability after the accession of Slovakia to the EU till 2012. According to the National Bank of Slovakia analytical data $(2011,2012)$ profit of the banking sector after the downturn in 2009 (a decrease of almost 51\%) reached in 2010 the level of EUR 513.9 million. In year to year change net profit of banks rose almost twice. The largest share on profit growth had an increase in net interest income due to the increase in the volume of provided loans (in particular loans for households to the population segment) for reasonable, relatively low interest rates in the market and increase in revenues from retail transactions. Relatively positive trend continued in 2010 and 2011 in response to global economic development. Year 2012 marked a new reduction in the profitability indicators and deepening of global risks.

Table 1. Development of selected profitability indicators in the banking sector in Slovakia

\begin{tabular}{llllllllll}
\hline Year & $\mathbf{2 0 0 4}$ & $\mathbf{2 0 0 5}$ & $\mathbf{2 0 0 6}$ & $\mathbf{2 0 0 7}$ & $\mathbf{2 0 0 8}$ & $\mathbf{2 0 0 9}$ & $\mathbf{2 0 1 0}$ & $\mathbf{2 0 1 1}$ & $\mathbf{2 0 1 2}$ \\
\hline $\begin{array}{l}\text { Net assets } \\
\text { millions of }\end{array}$ & $29,591.7$ & $37,993.2$ & $39,361.5$ & $50,920.1$ & $65,125.6$ & $55,787.1$ & $57,649.7$ & $58,976.2$ & $61,065.5$ \\
$\begin{array}{l}\text { EUR } \\
\text { Loans to } \\
\text { clients } \\
\text { millions of }\end{array}$ & $11,089.3$ & $15,420.7$ & $17,935.9$ & $24,508.4$ & $31,730.9$ & $31,876.2$ & $33,534.9$ & $36,412.3$ & $37,448.7$ \\
$\begin{array}{l}\text { EUR } \\
\begin{array}{l}\text { The volume } \\
\text { of clients' } \\
\text { deposits } \\
\text { millions of }\end{array}\end{array}$ & $19,660.9$ & $21,492.7$ & $24,859.1$ & $31,388.9$ & $38,982.6$ & $37,386.4$ & $39,487.8$ & $40,126.6$ & $41,621.3$ \\
\hline
\end{tabular}




\section{EUR}

\section{Net profit}

$\begin{array}{lllllllll}\begin{array}{l}\text { millions of } \\ \text { EUR }\end{array} & 407.87 & 462.10 & 523.66 & 582.66 & 508.59 & 278.75 & 513.87 & 674.24 \\ \begin{array}{l}\text { Net interest } \\ \text { income }\end{array} \\ \begin{array}{l}\text { billions of } \\ \text { EUR }\end{array}\end{array}$

Source: author's calculations and processing according to the NBS annual reports and SBA statistics

The leader position on the Slovak banking market belongs to four universal commercial banks: Slovenska sporitelna, VUB Bank, Tatra Bank and CSOB Bank Slovakia. ISTROBANK had not significant position on the market, previously belonging to the BAWAG AG PSK Group. The major merger between UniBank and HVB Bank Slovakia occurred on the banking market in Slovakia in 2007, this merger was finally approved in February 2007 and the shares of UniCredito Italiano were transferred to Bank Austria Creditanstalt A. G. Vienna. In April 2007, the merger took place by consolidation of obligations, assets and equity of HVB Bank Slovakia at UniBank by combining these two commercial banks with very different strategy, a new universal bank UniCredit Bank Slovakia with important strategic position in the banking market in Slovakia was formed. In 2001 UniBank (formerly Polnobank) was taken over by Italian investor group UniCredito (UniCredit, 2007). The important merger/acquisition on 1st July, 2009 was the merger/acquisition CSOB Bank and ISTROBANK. In 2009, the most significant project of CSOB Bank was its merger/acquisition of ISTROBANK. CSOB Bank, the member of CSOB Financial Group, became its legal successor, who took over all rights and obligations of ISTROBANK. The new bank started to operate in the market under the trade brand CSOB Bank Slovakia.

\subsection{The Empirical Evidence Database for Bank Merger/Acquisition in Slovakia}

In the context of the collected data from annual CSOB Bank reports several problems that can affect the quality of regression analysis and prediction of profit between years 2009-2011 can be encountered:

1) The length of time series data;

2) Changes in the bank annual reports;

3) The currency change (accessing the euro in Slovakia in January 2009);

4) The years of global crisis 2008-2009 and increasing financial risks (Mirdala, 2012).

Data are reported in millions CZK/EUR until 2008, since 2009 in thousands EUR, whereby the annual reports state for the individual years exchange rate CZK to EUR. The euro was introduced on January 1, 1999, when it became the new official currency of 11 member states, replacing the previous national currency units. Now the euro area comprises the 18 European Union countries that have introduced the euro. Therefore, for the data from 1997 and 1998 was used the first existing exchange rate CZK/EUR, which could have also affected the quality of the results obtained. A change of the currency in Slovakia also had economic impacts on the bank's performance.

All the input data used in this analysis and the results are given in thousands EUR (excluding the financial ratios as $l i q$ and $c p p \_a$ ). The overview of the development of individual indicators that were used for this empirical regression analysis, are shown in the following table 2 : 
Table 2. The development of variables in years 1997-2011—Statistics for regression modelling

\begin{tabular}{lllllllll}
\hline Year & $\begin{array}{l}\text { Profit } \\
\text { in } \\
\text { th.EUR }\end{array}$ & VKUK & UVUN & SKCK & PROP & Liq & OPVPN & CPP_A \\
\hline 1997 & $7,744.3$ & $9,598.7$ & $2,1140.3$ & $68,281.2$ & $402,759.5$ & 1.1 & $-2,590.6$ & -1.07 \\
1998 & $8,743.4$ & $-8,793.2$ & $2,5062.3$ & $76,116.8$ & $491,818.4$ & 1.1 & -343.2 & -2.07 \\
1999 & $7,813.5$ & $81,516.7$ & $19,349.6$ & $87,124.3$ & $531,826.7$ & 0.98 & $4,115.7$ & 3.89 \\
2000 & $13,368.5$ & $525,275.0$ & $45,773.7$ & $97,851.2$ & $617,936.7$ & 0.75 & $28,022.2$ & 0.89 \\
2001 & $18,611.6$ & $738,796.1$ & $62,695.4$ & $118,364.6$ & $888,202.0$ & 1.26 & $38,336.5$ & 2.28 \\
2002 & $20,857.6$ & $647,028.5$ & $43,420.9$ & $130,617.1$ & $1,275,151.9$ & 0.62 & $17,674.1$ & -4.26 \\
2003 & $19,842.6$ & $647,636.5$ & $45,448.9$ & $141,934.6$ & $1,081,194.1$ & 0.66 & $21,980.9$ & 0.41 \\
2004 & $21,674.0$ & $66,4101.8$ & $49,755.0$ & $144,651.4$ & $1,310,194.7$ & 0.72 & $17,204.8$ & 0.08 \\
2005 & $34,681.0$ & $782,652.8$ & $52,941.6$ & $179,573.5$ & $1,744,714.6$ & 0.63 & $6,135.0$ & 3.64 \\
2006 & $33,673.3$ & $653,973.2$ & $64,290.8$ & $144,682.4$ & $1,177,417.1$ & 0.87 & $18,041.6$ & -5.31 \\
2007 & $39,038.2$ & $612,824.2$ & $76,361.7$ & $175,183.7$ & $1,460,046.8$ & 0.85 & $21,876.8$ & -0.83 \\
2008 & $37,138.0$ & $-12,684.0$ & $106,292.0$ & $487,316.0$ & $3,082,455.0$ & 0.76 & $35,754.0$ & 0.41 \\
2009 & $-16,428.0$ & $189,493.0$ & $161,296.0$ & $569,505.0$ & $3,602,614.0$ & 0.43 & $98,097.0$ & 0.49 \\
2010 & $51,656.0$ & $46,106.0$ & $188,397.0$ & $590,106.0$ & $3,765,924.0$ & 0.39 & $84,778.0$ & -0.03 \\
2011 & $55,370.0$ & $-402,098.0$ & $187,962.0$ & $569,505.0$ & $4,362,550.0$ & 0.38 & $112,471.0$ & -0.02 \\
\hline
\end{tabular}

Source: authors processing based on Annual reports of CSOB Bank

Development of earnings, profit of commercial banks in thousands EUR prior to the merger/acquisition is shown in the following figure 1 .

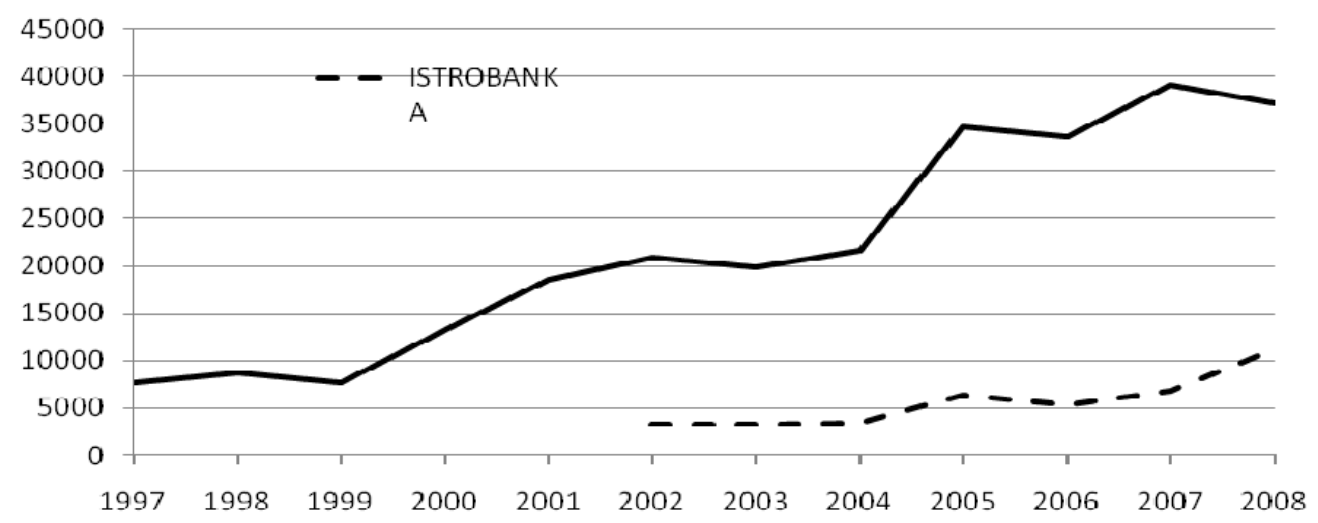

Figure 1. Development of earnings, profit of commercial banks (CSOB and ISTROBANK)

Source: authors processing based on Annual reports of CSOB Bank

Using the regression analysis, the importance of selected factors (the difference between customer deposits and loans (vkuk, $\mathrm{x}_{1}$ ), the difference between interest income and expenses (uvun, $\mathrm{x}_{2}$ ), difference between other operating income and expenses (opvpn, $\mathrm{x}_{6}$ ), the difference between total capital and liabilities (skck, $\mathrm{x}_{3}$ ), difference between receivables and value adjustments and reserves to cover credit risk (prop, $\mathrm{x}_{4}$ ), the ratio of current assets and current liabilities (liq, $\mathrm{x}_{5}$ ) and the share of net operating income and total assets (cpp_a, $\left.\mathrm{x}_{7}\right)$ ) was estimated for the period 1997-2008 to determine the dynamics of net operating profit of CSOB Bank. 


\subsection{Results-The Projection of the Novel Regression Model of M\&A in Slovakia}

To test the stationarity of time series The Widespread Dickey-Fuller test (Augmented Dickey-Fuller test, ADF test) has been used for VKUK (table 3) and then for all independent variables. The first test results show that the variables time series are non-stationary and need to be further adjusted. Logarithm of these variables was elected.

Table 3. ADF test for variable VKUK - Adjusted

\begin{tabular}{|c|c|c|c|c|}
\hline \multicolumn{3}{|c|}{ Dickey-Fuller test for unit root } & $\begin{array}{l}\text { Number } \\
\text { observato }\end{array}$ & 10 \\
\hline & \multicolumn{4}{|c|}{ Interpolated Dickey-Fuller } \\
\hline & Test & $1 \%$ Critical & $5 \%$ Critical & $10 \%$ Critical \\
\hline & Statistic & Value & Value & Value \\
\hline $\mathrm{P}(\mathrm{t})$ & -3.421 & -3.75 & -3 & -2.63 \\
\hline \multicolumn{3}{|c|}{ MacKinnon approximate $p$-value for profit(t) } & $=$ & 0.0103 \\
\hline
\end{tabular}

Source: authors calculating based on software STATA

The results of the multiple linear regression analysis are presented in the following Table 4:

Table 4. Linear regression

\begin{tabular}{|c|c|c|c|c|c|c|}
\hline & & & & \multicolumn{2}{|c|}{ Numbers of Observatories } & 1 \\
\hline & & & & \multicolumn{2}{|l|}{$\mathrm{F}(7,3)$} & 548.35 \\
\hline & & & & \multicolumn{2}{|l|}{ Prob $>$ F } & 0.0001 \\
\hline & & & & \multicolumn{2}{|l|}{ R-squared } & 0.9891 \\
\hline & & & & \multicolumn{2}{|l|}{ Root MSE } & 0.01797 \\
\hline \multirow[b]{2}{*}{ Profit } & \multirow[b]{2}{*}{ Coef. } & Robust & & \multirow[b]{2}{*}{$\mathbf{P}>\mathbf{t}$} & & \\
\hline & & Std. Err. & $\mathbf{t}$ & & \multicolumn{2}{|c|}{ [95\% Conf. Interval] } \\
\hline Vkuk & 0.012 & 0.0029 & 3.98 & 0.03 & 0.002 & 0.021 \\
\hline Uvun & 0.592 & 0.0269 & 22.03 & 0.00 & 0.507 & 0.678 \\
\hline Skck & -0.440 & 0.0596 & -7.39 & 0.01 & -0.630 & -0.251 \\
\hline Prop & 0.426 & 0.0743 & 5.73 & 0.01 & 0.190 & 0.662 \\
\hline Liq & -0.001 & 0.0003 & -3.71 & 0.03 & -0.002 & 0.000 \\
\hline Opvpn & -0.031 & 0.0056 & -5.58 & 0.01 & -0.049 & -0.013 \\
\hline cpp_a & 0.069 & 0.0056 & 12.15 & 0.00 & 0.051 & 0.087 \\
\hline Constant & 0.041 & 0.0066 & 6.32 & 0.01 & 0.021 & 0.062 \\
\hline
\end{tabular}

Source: authors calculating based on software STATA

Based on the results of the regression analysis, it can concluded that all explanatory variables chosen are at significance level of $5 \%$, significant to explain the dynamics of profit development of CSOB Bank, since their p-values are less than 0.05 . In addition, the importance of individual variables was tested, also the significance of the whole set of selected variables can be tested. Using the F-test the model of net operating profit of CSOB Bank and the statistical significance of the model as a whole was found. Variables are together significant (or it can be stated that at least one variable is different from zero) at the significance level of $5 \%$, whereas the p- value is less than 0.05 . This simply means that there is a significant difference between the model that contains all of these variables and one that does not and there is also a significant difference between the full and the reduced model. According to the coefficient of determination (R-squared) model, the model as a whole explains the 
development of earnings at $98.91 \%$.

The regression model is then based on the general linear equation in the following form (4):

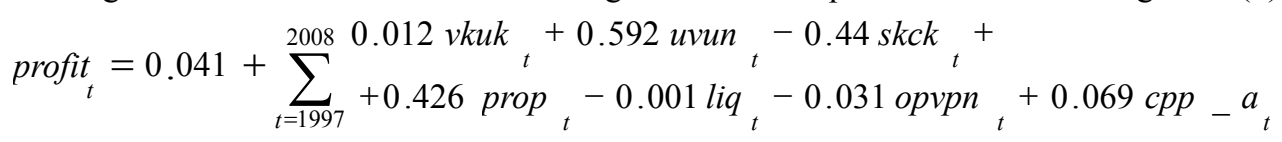

Net operating profit of CSOB Bank is constantly growing each year by 0.041 percentage point compared to the previous year. Wherein, moreover, if the difference between customer deposits and loans $(v k u k)$ increases during the period by 1 percentage point, net operating income will increase by an additional 0.012 percentage points. In addition if in the given period net interest income was growing ( $u v u n$ ) by 1 percentage point, then there is an additional profit growth by 0.592 percentage point (by about 60 basis points).

Conversely, an increase in the difference of total capital and liabilities (skck) by 1 percentage point leads to reduced earnings by 0.440 percentage point. Considering that liabilities decrease the profit of the commercial bank.

If it is assumed that reducing the volume of risky receivables (defaulted, non-performing loans, when the bank has identified that loans have lost more than $50 \%$ of their value or that a client-debtor is in arrears with payment more than 90 days) indicates a decreasing level of value adjustments and reserves (prop). And also the reduction of credit risk, then if the difference between receivables and value adjustments and reserves to cover credit risk increases by 1 percentage point, the profit will also increase by 0.426 percentage point.

Another factor is suggesting that the bank liquidity increase (liq) by 1 percentage point leads to reduced earnings by 0.001 percentage point. Liquidity, however, is in most periods below 1.0 (limited liquidity) and with the proceeding time decreased significantly (in 1997 was 1.1 but in 2008 only 0.76), and also its increase represents still insufficient liquidity and therefore it is likely seen as negative and means liquidity risk.

The difference between other operating income and expenses (i.e. excluding interest income and expense) effects the development of profits also negatively and so the growth in net other operating income (opvpn) by 1 percentage point reduces the profit of -0.031 percentage point. It seems that the decrease in net operating income could stimulate profit growth, for example in the form of cost-effective investments in improving the administration, electronisation of banking services, staff training for advanced technology, increased costs for services promotion etc.

Last factor share of net operating income and total assets ( $\left.c p p \_a\right)$ suggests that income growth per asset by 1 percentage point contributes to profit growth by 0.069 percentage point ( 6.9 basis points). It is expected that the determined beta coefficients are fixed and will not change in subsequent periods. Then based on the determined regression function development of earnings in subsequent periods - in 2009, 2010 and 2011 can be estimated. The objective is to compare the estimated profit development with the really achieved one and analyze whether the regression model, calibrated for the period prior to the merger, is able to estimate the real profit development of CSOB Bank also after the merger/acquisition.

Based on the regression model, the percentage change in net operating profit in subsequent periods - in 2009, 2010 and 2011, in thousands EUR was estimated. 2008 is the last year, which was used in the regression analysis. For better comparability of data it was included in the following table 5 presents earnings estimates and actual results achieved pursuant to the bank's annual reports of the years:

Table 5. The development of net profit for year-estimated versus real (in thousand EUR)

\begin{tabular}{lllll}
\hline Year & Estimated & Real & \multicolumn{2}{l}{ Year- to- year change } \\
\hline 2008 & $37,138.00$ & $37,138.00$ & Estimated & Real \\
2009 & $59,043.49$ & $-16,428.00$ & $21,905.49$ & $-53,566.00$ \\
2010 & $70,595.58$ & $51,656.00$ & $11,552.09$ & $68,084.00$ \\
2011 & $73,363.70$ & $55,370.00$ & $2,768.12$ & $3,714.00$ \\
\hline
\end{tabular}

Source: authors processing based on Annual reports of CSOB Bank Slovakia (2011) 
Graphical representation of the profit development after the introduction of the merger and the comparison of the profit resulting from the proposed model and actually achieved profit shows in the Figure 2.

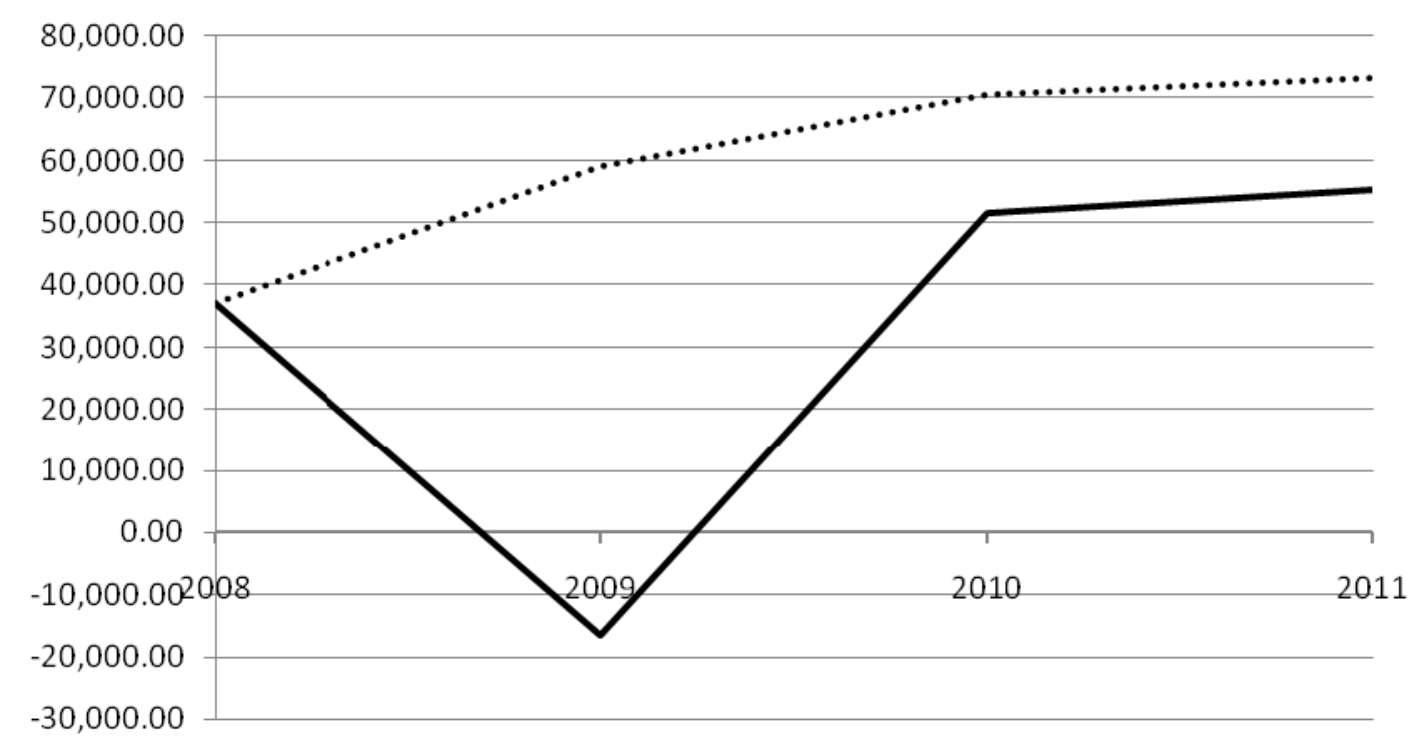

Figure 2. The profit development of CSOB Bank Slovakia

Source: authors processing based on Annual reports of CSOB Bank Slovakia

Note. “---": real profit; “......”: estimated profit

Based on the regression model of profit development it can be concluded that in both cases (real development and estimated development) the upward trend is prevailing. In 2008, the financial crisis broke out, that developed into a global economic and financial crisis in the next period. At the same time in 2009, the merger/acquisition of the two banks took place, which might explain why the bank exhausted itself, and why there is a sharp drop in its profits. In addition, in 2009, Slovakia adopted a new currency, the euro, which also has been associated with considerable costs. For example, the currency conversion in CSOB Bank employed a total of nearly 600 employees, had to be changed more than 120 applications and the actual conversion required the implementation of about 2,200 separate tasks. This project lasted for nearly three years. According to the CSOB annual report introduction of the euro has ultimately contributed to a significant growth in customer deposits. The merger/acquisition has been associated with several significant cost - the cost of technical migration of branches, customers and products of ISTROBANK to CSOB systems, which also had an impact on the financial situation of the bank. According to the CSOB annual report from 2009, profit was affected by the introduction of the euro, the global crisis and also the costs associated with the merger of CSOB Bank and ISTROBANK and the creation of one-time reserves.

In the following years gradually coping with the situation inside the bank and on the market resulted in the bank's real profit growth again. Growth in 2010 is also supported by the results of the projected model. Significant real growth in 2010 over the previous year may be due to the positive impacts of mergers that have become apparent in the following period, but also because of the bank's adjustment to the negative consequences of the crisis. In 2011, the upward trend continues, whether by actual data or by estimated bank's profit for this year. It should be noted that the quality of additional estimates is progressively reducing. In 2012 and 2013 the profit growth trend further continues in numbers $(55,746.00$ and 63,065.00 in thousand EUR) and CSOB Bank Slovakia become the number four on the banking market in Slovakia and fulfilled the aim to increase its market share and market power. The research hypothesis $\mathrm{H}_{1}$ was confirmed only as a prediction for next years. Liquidity risk and credit risk affect the financial performance of the bank most of all risks, was observed in $\mathrm{H}_{2}$.

\section{Conclusion}

The main findings: The novel linear regression model of profit of bank M\&A in Slovakia, applied by the methodology of European banks, is acceptable for analyses and applicable for growth projections of net operating profit after implementing the merger/acquisition as a potential model of financial management. On the other hand, it seems that in reality after 2008, the importance of each factor is subdued by the market situation 
(the ongoing effects of the global crisis) and also by adapting to the new conditions inside the commercial bank (the merger). Therefore, on the basis of this analysis and the research hypothesis, it cannot be definitely confirmed that the bank merger had a positive impact on the profit development of CSOB Bank; neither definitely decide whether the lower level of profit was caused by merger or crisis. Because of this reason, for further study in this area is advised to focus the research on improving the existing regression model of profit, for example, while watching unforeseen risks of bank in connection with the profit development in the global market. It would be necessary to project additional variables, extend the time series and incorporate them into the model so they would be able to better quantify the potential financial and market risks of banks with an impact on the financial stability and performance of the banking sector. The findings in this study in banking sector of Slovakia can be compared with previous empirical studies and outline next development in other countries of the EU.

Next findings: One benefit, value added of this regression analysis of bank merger/acquisition, associated with effects of M\&A is the fact that commercial banks can create more precise analyses and models and estimate the future development in entrepreneurship by using the historical data. This regression model, based on the methodology of empirical European studies and others, makes it simpler for managers to better predict the future bank development trends, growth strategies, more effectively allocation of capital, plan current costs and revenues more effectively, more accurately determine the strategic objectives of the commercial bank (in particular increasing its profitability on a longer term basis, efficiency, acquire a greater share of the market, specific products targeting to meet the needs of its clients) and use more efficiently instruments of controlling business and financial risks. Based on effects of mergers and acquisitions is possible predict trends in the area of financial performance of banking sector and outline implications for corporate governance and strategy. According the Basel III, in November 2013, the European Central Bank started the stress testing of European banks in order to assess their stability and resistance against risks. The banking sector in Slovakia is considered as a stable sector in euro area (according to the Index of Bank Soundness, in Global Competitiveness Report 2012, 2013).

In the area of identified risks it is still necessary to apply more effective models of risk regulation, stiffer internal rating systems, and quality techniques to mitigate financial risks, implement proactive monitoring and strategy risk prevention, streamline the management of quality bank credit transactions, and minimize bank's credit risk. One of the major trends in banking, in addition to the rules of international regulation of Basel III, is the diversification of risks within the risk management and establishment diversified loan portfolios to ensure adequate bank liquidity, profitability of the banking sector and acceptance of risks involved in the real economy. These results can be associated with findings of Poloucek et al., (2006) and with empirical studies by Cornett and Tehranian (1992), Punt and van Rooij (1999), Altunbas and Marques (2004, 2008), Lepetit et al. (2008), Stavarek and Sulganova (2009), Aebi et al.(2012). Credit risk associated with the quality of credit portfolio, liquidity risk and bank market power are the most important factors in bank strategies, according to Cipollini and Fiordelisi (2012). In this interesting and dynamic field of banking are still many opportunities for further scientific research for country researchers, scientific and economic debate with the newest knowledge applied in managerial practice.

These effects have to direct the EU banking sector to a more efficient, active and high-quality management of liquidity and rate of return, management of long-term profitability, of high-quality of balance sheet structure, interest policy and credit risk, in response to the expected development of interbank interest rates on financial markets and to promote banking sector competitiveness, growth and financial performance and stability in the succeeding period. From the aspect of strategic development and consolidation and integration of processes, the processes of cross-border mergers and acquisitions and risk controlling implemented on an international scale, must also be more implemented in the economy of the Slovak Republic within the European Union.

\section{Acknowledgements}

This study was created as a part of the research project VEGA No.1/0054/14 titled "Research in the area of controlling the risks of entrepreneurship in the EU with a focus on the design of models to streamline effective solutions and forecasting financial risks of businesses," researched and solved at the Faculty of Management, University of Presov in Presov, Slovak republic, with financial support of Ministry of Education, Research, Science and Sport of the Slovak Republic.

\section{References}

Aebi, V., Sabato, G., \& Schmid, M. (2012). Risk management, corporate governance, and bank performance in the financial crisis. Journal of Banking \& Finance, 36(12), 3213-3226. http://dx.doi.org/10.1016/j.jbankfin.2011.10.020 
Altunbas, J., \& Marques, D. (2004). Mergers and Acquisitions and Bank Performance in Europe: The Role of Strategic Similarities. Journal of Economics and Business, 60(3), 204-222. http://dx.doi.org/10.1016/j.jeconbus.2007.02.003

Bobakova, V. (2003). Possibilities of the increasing of the profitability of a commercial bank. Biatec, 11(4), 26-29.

Cipollini, A., \& Fiordelisi, F. (2012). Economic value, competition and financial distress in the European banking system. Journal of Banking \& Finance, 30(11), 3101-3109. http://dx.doi.org/10.1016/j.jbankfin.2012.07.014

Cipra, T. (2008). Financial Econometric (2nd ed.). Prague: Ekopress.

Cornett, M. M., \& Tehranian, H. (1992). Productivity Effects of Bank Mergers (Changes in Corporate Performance Associated with Bank Acquisitions). Journal of Financial Economics, 31(2), 211-234. http://dx.doi.org/10.1016/0304-405X(92)90004-H

CSOB Annual Report. (2011). Retrieved http://www.csob.cz/cz/csob/relationships-to-investors/Pages/Annual-and-biannual-reports.aspx

Dietrich, A., \& Wanzenried, G. (2011). Determinants of bank profitability before and during the crisis: Evidence from Switzerland. Journal of International Financial Markets, Institutions and Money, 21(3), 307-327. http://dx.doi.org/10.1016/j.intfin.2010.11.002

Heckova, J., \& Chapcakova, A. (2009). Development trends in the area of mergers in the European region. Biatec, 17(3), 19-23. $\quad$ Retrieved from http://www.nbs.sk/_img/Documents/_PUBLIK_NBS_FSR/Biatec/Rok2009/biatec0309.pdf

Heckova, J., Chapcakova, A., Kiselakova, D., \& Hrabovska, Z. (2012). The view on mergers and acquisitions from aspect of theory. ANNO 2012, 122-131. Retrieved from http://www.pulib.sk/elpub2/FM/Kotulic17/pdf_doc/12.pdf

Horvathova, J., \& Mokrisova, M. (2013). Analysis of key performance indicators and creation of the model comparing the performance of entities as a management tool in the energy industry. Management: Science and education: Slovak scientific Journal, 2(2), 38-40.

Houston, J. F., \& Ryngaert, M. D. (1994). The overall gains from large bank Mergers. Journal of Banking \& Finance, 18(6), 1155-1176. http://dx.doi.org/10.1016/0378-4266(94)00065-4

Kiselakova, D. (2010). Management of credit risk of banks in Slovakia and risks in context of global crisis. ECONOMIC REVUE-ER-CEREI, 13(1), 5-17. http://dx.doi.org/10.7327/cerei.2010.03.01

Kiselakova, D., et al. (2011). Management of bank credit trades and its effects on economy, credit financing and competitiveness of business entities in Slovakia and euro area in context of global crisis and an ensuing development (pp. 160-200). Presov: University of Presov.

Lepetit, L., Nys, E., Rous, P., \& Tarazi, A. (2008). Bank income structure and risk: An empirical analysis of

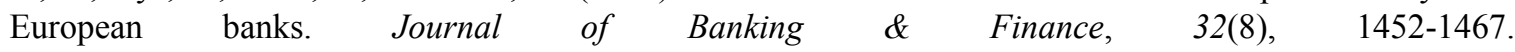
http://dx.doi.org/10.1016/j.jbankfin.2007.12.002

Mirdala, R. (2012). Interest Rates Determination and crisis Puzzle (Empirical Evidence from the European Transition Economies). Journal of Applied Economic Sciences, 7, 418-436.

Poloucek, S., et al. (2006). Banking (1st ed., pp. 470-532). Prague: C. H. BECK.

Punt, L. W., \& van Rooij, M. C. J. (1999). The Profit-structure Relationship and Mergers in the European Banking Industry: An Empirical Assessment. Retrieved from http://www.dnb.nl/binaries/wo0604_tcm46-145922.pdf

PWC. (2013). Sharing deal insight European Financial Services $M \& A$ news and views. Retrieved from http://www.pwc.com/en_GX/gx/financial-services/european-mergers-acquisitions-industry-trends/assets/pw c-sharing-deal-insight-european-financial-services-m-and-a-news-and-views-v2-pdf

Sivak, R., Gertler, L., \& Kovac, U. (2009). Risks in finance and in banking (1st ed., pp. 151-181). Bratislava: Sprint two.

Smolkova, E. (2009). Strategic partnerships as phenomena of global economy (2nd ed.). Bratislava: Infopres.

Sobek, O. (2000). Bank Mergers and acquisitions. Biatec, 8(12), 2-4. Retrieved from http://www.nbs.sk/_img/Documents/_PUBLIK_NBS_FSR/Biatec/Rok2000/BIATEC_12_2000.pdf

Sofrankova, B. (2013). An analytical view on development of mergers and acquisitions in the world and in the 
Europe. Exclusive Journal: Economy \& society \& environment, 1(1), 14-22.

Stavarek, D., \& Sulganova, J. (2009). Analysis of the efficiency of Slovak banks using Stochastic Frontier Approach. ECONOMIC REVUE-ER-CEREI, 12(1), 27-34. http://dx.doi.org/10.7327/cerei.2009.03.03

The Global Competitiveness Report 2012-2013. (2013). Index of Bank Soundness (pp. 320-321). Slovakia. Retrieved from http://www3.weforum.org/docs/WEF/The Global Competitiveness Report 2012-2013.pdf

UNICREDIT. (2007). Annual reports-Information for investors. Retrieved from http://www.unicreditbank.sk/sk/About-bank/Information-for-investors/Annual-Reports

Walter, I. (2004). Mergers and acquisitions in Banking and Finance: What Works, What fails, and Why? (1st ed.). Oxford University Press.

\section{Copyrights}

Copyright for this article is retained by the author(s), with first publication rights granted to the journal.

This is an open-access article distributed under the terms and conditions of the Creative Commons Attribution license (http://creativecommons.org/licenses/by/3.0/). 